\title{
Students' Lived Experience on The Toughest Place to be a Binman in Critical Listening and Speaking 1 Class
}

\author{
Martha Pritzanda Pudhika \\ Sanata Dharma Univeristy, Yogyakarta
}

\begin{abstract}
The use of authentic videos has been implemented in Critical Listening and Speaking 1 (CLS 1) class. For instance, the use of The Toughest Place to be a Binman video. This video gives the students meaningful experiences. The students do not only get the material but they can also get social and environment issues that appear in the video. After watching the video, the students are expected to have their own experience towards the use of The Toughest Place to be a Binman video in CLS 1. Therefore, the aim of this research was to have a better understanding on the students' lived experience on The Toughest Place to be a Binman in CLS 1. This research employed phenomenology study because this research focused on the students' lived experience. As a research result, the research showed the participants' stories and the interpretation. There were four emerging themes that appeared from the data processed. Those were meaningfulness, compassion, motivation, and action. Those four themes connected between each other.
\end{abstract}

Keywords: lived experience, The Toughest Place to be a Binman, CLS 1

\section{Introduction}

The uses of authentic videos in English learning are not the new techniques of teaching, especially for the 21 st-century learners. Smaldino (2012) says that video can facilitate the students to learn and to prepare them for the real work in the future. Yousef, Chatti, \& Schroeder (2014) also believe that video-based learning is a rich and powerful model used in English second language class to improve the learning outcomes as well as the learners' satisfactions. Marshall (2002) says "the ability of authentic video to engage the learner, activate emotional states, initiate interest in a topic, and allow for absorption and processing of information can make meaningful learning” (p.7).
Authentic videos also serve as a bridge for the students to relate their classroom condition into their real world. As an addition, Jonassen (2000) says that learners should be facilitated with many opportunities to interact with the society around them. The main purpose of doing it is to help them visualizing the world through authentic videos. Videobased learning also brings some advantages for the students. Smaldino (2012) finds seven advantages of video-based learning. Those are motion, risk-free observation, dramatization, affective learning, problem-solving, cultural understanding, establishing togetherness. Joynt (2008) states that language model also is one of the advantages of video-based learning. 
In English Language Education Study Program of Sanata Dharma University, the uses of authentic videos also have been implemented in Critical Listening and Speaking 1 (CLS 1) and those videos were used by the lecturers as one of the media in CLS 1 course. According to the English Language Education Study Program, Sanata Dharma University Academic Guidance (2012), Critical Listening and Speaking 1 Course is designed to introduce students to various listening materials focusing on giving a personal respond. The course requires the students to employ integration skill in order to comprehend and to summarize the advanced extended discourse. Therefore, for the outcomes, the students are asked to give critical oral responds and reflections based on the topic in the form of individual or group presentations. Critical Listening and Speaking 1 encourages the lecturers and learners to think about the sociopolitical nature of the texts to which they listen, certainly an important consideration in an interconnected world. Therefore, the reasons why the videos were used in the class were to support the material and to attract CLS 1 students' interest in the topics were taught in the class. In teaching learning activity, the videos facilitate students to visualize the real world and the recent things that happen. Furthermore, the videos are expected to give students experiences and to make them realize both explicit and implicit messages in the videos.

One of the videos which was played in the CLS 1 is The Toughest Place to be a Binman. This video may carry a very meaningful message for the students. The video entitled The Toughest Place to be a Binman is a documentary video from BBC UK. This video tells the audience about the experience of an English binman who heads to Jakarta and tries to live like an Indonesian binman. The conditions in Jakarta are very different from his origin. Jakarta has many problems with waste managements. Meanwhile, London has great management not only on the trash but also for the binmen themselves. Furthermore, after watching The Toughest Place to be a Binman video, the students are expected to be more aware of the environment around the students, especially the trash. In other words, this video is expected to increase the students' environmental awareness. Kolmuss \& Agyman (2002) define environmental awareness as an individual perception on the impact of human activities and the environment. Dunlap \& Jones (2002) as cited in Yadav \& Pathak (2013) state that environmental awareness is "the degree to which people are aware of problems regarding the environment and support efforts to solve them or indicate the willingness to contribute personally to their solution" (p. 2938). The more someone has awareness about environmental issues, the more he has pro-environmental behavior. Hines, Hungerford \& Tomera (1987) as cited in Yadav \& Pathak (2013) also argue that an environmental awareness and pro-environmental behavior have a direct relationship.

According to Kollmus \& Agyman (2002), a pro-environmental behavior is "a behavior that 
consciously seeks to minimize the negative impact of one's actions on the natural and built world" (p.240). Pro-environmental behavior is a real action that the people do for the environment around them. There are some aspects that influence proenvironmental behavior based on Ajzen and Fishbein's theory as cited in Kollmus \& Agyman (2002). First is knowledge of issues. In this aspect, environmental problem and issues have to be known well because it will be the knowledge for a person. Second, knowledge of action strategies which lead the person to know how she/he helps to decrease the environment damage. Third is locus control which related to an individual perception about their ability to do changes. Fourth, attitudes also influence proenvironmental behavior. The stronger the attitudes, the more proenvironmental behavior is achieved. Next is verbal commitment. A verbal commitment is defined as a communicated willingness to have some action towards the environment and also showed the willingness to the other people that he/she wants to engage in a pro-environmental behavior. Last, an individual sense of responsibility. Someone who wants to have a pro- environmental behavior must have a high individual sense of responsibility because the higher people's responsibility toward the environment, the closer they engage in a pro-environmental behavior.

From that perspective, the researcher argues that The Toughest Place to be a Binman will give students environment knowledge and motivate the students to be more aware of environment around them which will also lead them to be better people. The students are also expected to have good environmental experiences after watching this video. The students can do some action related to the environment and social conditions in their surroundings, such as respecting other people, making environment to stay clean, or doing any campaign about environment. Therefore, the aim of this research is to find out more about the students' lived experience on The Toughest Place to be a Binman video in CLS 1. This research

\section{Methodology}

This research used qualitative research as the research method. Ary et al. (2010) state that the aim of qualitative research is to find and understand the holistic picture and depth understanding of a phenomenon. Therefore, this research aimed to draw the holistic picture and get a better understanding of students' lived experience after watching The Toughest Place to be a Binman video in CLS 1. In qualitative research, the researcher must also attempt to understand the participants' reality. Hence, the intended result is a rich description, so that the researcher can understand the reality which is experienced by the participants. Then, in order to answer the research question, the researcher designed this research employing phenomenological studies. Manen (1990) stated that a phenomenological study is a study of someone's lived experience. 
This research also used the in-depth interview as the primary data collection and reflection as the secondary data collection. It also attempted to determine the meaning of the participants' thoughts and feelings. Therefore, the participants of this research were the students of English Language Education Study Program who have done their CLS 1 Class in academic year 2014/2015. The participants were those who have had direct experience of this phenomenon (Marriam, 2009). Kruger (1988) also adds that the participants of phenomenological study are those who have good verbal communication and are able to express their feeling, thought, and perception towards the topic. The data obtained from the participants were analyzed by following elaboration steps from Moustakas (1994) and Van Kaam method (1959 \& 1966) as cited in Moustakas (1994) to answer the research question. Those steps were epoche, phenomenological reduction, clustering and thematizing, imaginative variation, and synthesis meaning and essence.

\section{Findings and Discussion}

There are two parts of findings. First is a text description which explains about participants' background. Second is an interpretation which discusses the interpretation of the findings. The text description discusses participants' background which includes participants' personal identities, their motivations to learn English, their learning styles, their perceptions about English skills and their integrations. This part also discusses the implementation of video-based learning in CLS 1 on participants' perspectives and also about The Toughest Place to be a Binman video in general.

\section{Participant A's Story}

His motivation to learn English because he realized that English would be beneficial for him especially in this globalization era. $\mathrm{He}$ preferred to learn English in silence or in a peaceful moment because he could understand class materials easily. In addition to it, he also preferred listening to music when he was studying. He used to listen to someone's talking. He also enjoyed speaking than writing because he did not like writing. However, he said that four English skills were important. Those skills were related one and another; for instance, listening and speaking. Meanwhile, CLS 1 for him was a course which focused on listening and speaking skills. However, this course did not only focus on those two skills, but it also encouraged CLS 1 students to learn deeper about listening and speaking. Next, he expressed his perspective about the use of video-based learning in CLS 1. He said that videos gave him some moral values which are delivered in each video. Thus, he did not only get the material but also the moral value because he could see the real example of his life. He also said that the use of videos helped him because he did not need to imagine the situation, but he could see the image and also listen to audio at once. He likes humorous videos. He did not like motivational videos which had expressionless speakers. He saw The 
Toughest Place to be a Binman video for the first time in CLS 1 . He said that the video was about a job exchange between an Indonesian binman and an English binman.

\section{Participant B's Story}

His motivation in learning English was for preparation for his future jobs. He realized that someday he would face globalization era where English language ability was one of the requirements as an employee candidate. He realized that by learning English, he would have more chance of getting jobs. He used to learn English without any pressure. He said that the learning process could be easily understood if classroom condition was quite. In learning English, he believed that four English skills were important for him. The skill that he preferred the most was listening. However, he did not really prefer speaking because he did not feel comfortable when he had to present something in front of people. He said that CLS 1 course was identical with listening. In CLS, he listened and watched videos, then wrote the messages that he got from the videos. After that, he presented what he got in front of the class. He preferred video-based learning approach because by watching videos, he did not need to imagine the situation. $\mathrm{He}$ also preferred documentary videos because he could see the real conditions and he also could see someone's daily activities without any dramatic effects. Watching The Toughest Place to be a Binman video in CLS 1 was his first experience for him. He said that the video was very memorable. He could know and understand social issues about the differences between an English binman and an Indonesian binman. This video also helped him to improve his competence, conscience, and compassion.

\section{Participant C's Story}

Her motivation in learning English was her realization that English was an international language. Therefore, she should master the language to prepare her future. She preferred learning English in a quiet condition. She said that integrated course was important for learning English because when she could master one skill, she could also master the other skills. However, among four English skills, she preferred speaking skill because, in her opinion, speaking was the simplest skill. Besides that, she did not like listening. She said that when she listened to English conversation, she could not easily understand the message. CLS 1 for her was a class which expected her to have critical thinking. Every time she listened to something, she had to have critical responses toward what she listened. The implementation on the use of videos in CLS 1 was very effective for her. The videos which were used in CLS 1 were also accessible videos. Therefore, she could easily find the subtitle to help her understand the video. She liked videos which provide real facts. The video that she remembered the most in CLS 1 was The Toughest Place to be a Binman video. She said that from the video, she could see big differences between an Indonesia binman and an English binman. 
In summary, those
participants, backgrounds could
affect their lived experiences on The
Toughest Place to be a Binman video
in CLS 1. The participant who
prefers listening skill has more
experiences on The Toughest Place
to be a Binman in CLS 1. The reason
why it happened because The
Toughest Place to be a Binman wass
one of the listening materials in CLS
1. Meanwhile, the participant who
had some positive perspectives
related to this research also had more
experiences on The Toughest Place
to be a Binman in CLS 1 .
Next finding interpretation. The interpretation showed the elaboration of the participants' answers which form four emerging themes. Those four themes that the researcher extracted are from in-depth interview results and also reflections from the participants. Those themes were meaningfulness, compassion, motivation, and action.

\section{Meaningfulness}

The implementation of The Toughest Place to be a Binman video in CLS 1 appeared as a media which could give the students meaningfulness. Meaningfulness, in this research, means that the students did not only get class materials but they also got some issues related to the real life. This video gave an enlightenment about what happened in the environment, especially about trash in Jakarta. Through the video, the participants learned about class materials which were about the environment, British accent, and also critical thinking. At the same time, the students also learned about social and environmental issues which were delivered through the video.

The environmental issue that clearly shown in the video was in London, all of the trash had already well-organized. However, it was different from Jakarta. Trash in Jakarta was not well-organized and unhygienic. Participant B also realized that the trash in London did not only has been well-organized but also supported by advanced technologies.

Meanwhile, the social issue that the participants got from the video was about the differences between an Indonesian binman and an English binman in term of proper life. The video showed that English binmen had a proper life. After working, they still had free time for their family or for entertainments. It is totally different from Indonesian binmen. They realized that some people in Indonesia still did not care about Indonesian binmen's life.

\section{Compassion}

The effect of the use of The Toughest Place to be a Binman video in CLS 1 was the students felt something different. The real condition showed in the video brought the participants to see the different condition between an Indonesian binman and an English binman. It helped the participants to realize the real condition of their surrounding and relate themselves to what the binmen might feel in doing their work. The condition when someone puts his/herself in others' feeling after watching them suffered is define as compassion (Goetz, Keltner, \& Thomas, 2010). 
After watching the video, participant $\mathrm{C}$ felt sad because she realized that people in London had high consideration in lessening the work of English binmen by separating the organic and nonorganic trash. People in London also gave the binmen a considerable payment in order to give them a proper life. However, in Jakarta, the people did not care about the environment around them, especially to Indonesian binmen.

However, at the first time participant B watched The Toughest Place to be a Binman video, he felt excited about English people because they classified their trash and it was supported by advanced technologies. In addition to that, when the video showed the negative sides of Jakarta, he was ashamed because usually in the television commercial, Indonesia was drawn as a beautiful country with the cleanliness. In fact, the video showed the negative sides of Jakarta that made him felt challenged to make Indonesia better.

Then, participant A experienced different feeling. After watching The Toughest Place to be a Binman video, he felt the sympathetic, envy, and shocked. He felt sympathy because the condition of Jakarta which was not wellorganized. He wanted to transform the environment around him to be better. He also felt the envies because Jakarta could not be like London which had already managed their trash properly. Through the video, he was also shocked because there was a big gap between Indonesia and London.

\section{Motivation}

The environmental and social issues that the participants got from The Toughest Place to be a Binman video led them to have better motivations. The motivations that appeared vary, from the simplest things, such as want to classify trash or not littering, until the biggest things, such as providing jobs or advanced technologies. It also came from motivation to change them individually. Then, the participants also wanted to change Indonesia to be better, especially related to environmental and social aspects. The participant also had an idea to provide proper job and advanced technologies for Indonesian binmen.

Participant B realized that he had to help other people. People only thought about their own life and they did not care about other people. However, the video made him see how hard a binman's life is. He had the courage to relieve a binman's life by avoiding the use of plastic and also classifying the trash between organic and non-organic. Thus, he also wanted to be something to other people. All of the participants had their own courage to make Indonesia better. Participants $\mathrm{C}$ had the courage to make Indonesia better by making the Indonesian people to realize and care about the environment around them. Participant B also wanted to make Indonesia better by giving the binmen proper jobs or facilitating them with advanced technologies.

The opinion uttered by participant A was different. After watching the video, participant $\mathrm{A}$ wanted to make Indonesia be a highdeveloped country. He would start from keeping the environment 
around him to stay clean. He believed that a movement should be started from himself.

\section{Action}

The participants did not only stop at having the motivation to do better. They also did some actions. In fact, The Toughest Place to be a Binman video gave a chance to the participants to have new knowledge and experiences, especially which were related to the environment around them. Some negative sides of Jakarta, such as unregulated trash and the condition of Indonesian binman that appeared in the video made the participants did something different. They did small things, but useful for the environment around them because big changes would normally start from small movements. They started doing the action from themselves by trying not to litter and avoiding the use of plastic bags. They also did some new things in their life, such as being grateful for whatever he/she had in life.

Participant A did something better than before. He usually collected the trash until his trash bin was full of trash, then he did not throw it directly. However, after watching The Toughest Place to be a Binman video, he did not postpone to throw his trash. He also started to clean the environment around him, such as his house and boarding house. Sometimes, he cleaned the environment together with his neighbors. After that, he became more aware of the environment. He did not only remember the video but also did the actions until now.
Moreover, participant $\mathrm{B}$ also did something different after he watched The Toughest Place to be a Binman video. He helped to make a better environment by reducing the use of plastic bags. He preferred to put his groceries in his bag; it made him felt that he was united with the environment. It also made him became more aware of the environment around him. He was also trying not to litter. He always threw his mineral water bottle in its place, even though some of his friends left their water bottles in the class.

Those also happened to participant $\mathrm{C}$, she also believed that big action should be started from herself. She was trying not to litter. However, she had something different from other participants. After she watched the video, she felt grateful. Through the video, she could see a lot of people who need a help, they were fighting for their life. Moreover, we who had proper life always complained or grumbled at everything. After that, she became more grateful with what she had. She also learned from English people how to be nice with the environment, especially trash.

\section{Conclusion}

The use of The Toughest Place to be a Binman video in CLS 1 successfully delivered the listening materials and also social and environmental issues to the participants, so that the participants had meaningfulness on The Toughest Place to be a Binman. After they got meaningfulness, they also had compassion. Through the video, the participants also learned about 
compassion and the participants showed their own feeling towards the video. The compassion also led the participants to have their own motivation to do something. The effects of the use of The Toughest Place to be a Binman video in CLS 1 did not only stop in the classroom and in their motivations, but it also facilitated them to do some actions in order to response the environmental and social problems. In conclusion, the participants had their own meaning and lived experiences after watching The Toughest Place to be a Binman video in CLS 1.

\section{References}

Ary, D., Jacobs, L. C., Razavieh, A., \& Sorensen, C. K. (2010). Introduction to research in education ( $8^{\text {th }}$ ed.). Belmont, CA: Wadsworth Publishing.

Goetz, J. L., Keltner, D., \& Thomas, E. S. (2010). Compassion: An evolutionary analysis and empirical review. Psychological Bulletin, 136(3), 351-374. Retrieved June $3^{\text {rd }}$, 2016, from http://dx.doi.org/10.1037/a0018807

Jonassen, D. (2000). Learning: As activity. The Meaning of Learning Project Learning Development Institute Presidential Session at AECT Denver. Retrieved November 15 ${ }^{\text {th }}$, 2015, from http://www.learndev.org/ $\mathrm{dl} /$ DenverJonassen.PDF

Joynt, R. (2008). Using authentic multi-media material to teach Italian culture: Student opinions and beliefs. Retrieved November $15^{\text {th }}$, 2015, from https://repositories.lib.utexas.edu/handle/2152/18128

Kollmus, A., \& Agyman, J. (2002). Mind the gap: Why do people act. Environmental Education Research, 8(3), 239-260. Retrieved February $20^{\text {th }}, \quad 2016$, from http://psychsustain.voices.wooster.edu/files/2014/ 01/Mind-Gap.pdf

Kruger, D. (1988). An introduction to phenomenological psychology. Cape Town: Juta.

Manen, M. V. (1990). Reseraching lived experience. Human science for an action sensitive pedagogy. Canada: State Univeristy of New York Press.

Marshall, J. (2002). Learning with technology: Evidance that techonology can and does, supporting learning. A white paper prepared for cable in the classroom. Retrieved October 14 ${ }^{\text {th }}, 2015$, from https://dcmp.org/ public_content/caai/naadh176.pdf

Merriam, S. B. (2009). Qualitative research: $A$ guide to design and implementation. San Francisco: Jossey-Bass.

Moustakas, C. (1994). Phenomenological reserach method. California: Sage Publications.

Smaldino, S. E. (2012). Instructional techonology and media for learning. Boston: Pearson Education, Inc.

Yadav, R., \& Pathak, G. S. (2013). Awareness about environmental issues: A study of female students. Tenth AIMS International Conference on Management, 2938-2942. Retrieved February 20 ${ }^{\text {th }}$, 2016, from https://www.academia.edu/3577294/Awareness_about_Environmental_Iss ues_A_Study_of_Female_Students 
Yousef, A. M., Chatti, M. A., \& Schroeder, U. (2014). Video-Based Learning: A Critical Analysis of The Research Published in 2003-2013 and Future Visions. eLmL 2014 : The Sixth International Conference on Mobile, Hybrid, and On-line Learning IARIA, 112. Retrieved December 5, 2015, fromhttps://www.researchgate.net/profile/Ahmed_Mohamed_Fahmy_You sef/publication/278707623_VideoBased_Learning_A_Critical_Analysis_o f_The_Research_Published_in_20032013_and_Future_Visions/links/5584 230f08 $\overline{8}$ aeff4ba $\overline{7} 2 \mathrm{ab} 58 . \mathrm{pdf}$ 